\title{
An Empirical Analysis On Perception of Investors' Towards Various Investment Avenues
}

\author{
G. Velmurugan ${ }^{1 *}$ \\ V. Selvam ${ }^{2}$ \\ N. Abdul Nazar ${ }^{3}$ \\ ${ }^{1}$ Associate Professor of Commerce, SSL, VIT University, Vellore, Tamil Nadu, India \\ 2 Professor of Commerce, SSL, VIT University, Vellore, Tamil Nadu, India \\ ${ }^{3}$ Assistant Professor of Commerce, SSL, VIT University, Vellore, Tamil Nadu, India \\ *Correspondence Author Email: gvelmurugan@vit.ac.in
}

Doi:10.5901/mjss.2015.v6n4p427

\section{Abstract}

Purpose: The economic liberalization and globalization have brought a fervent environment for the common and small investors who are willing to participate in the various investment avenues available in India. There are large number of small investors, who have the ability to save and make an investment in share market, gold, real estate, insurance and post office. In recent years, numerous researches have been conducted on investors' perception towards various investment from various perspectives. From a survey on investment literatures of equity, insurance, and mutual fund perspective, there are some studies based on the investment on various avenues made by researchers. However, the investors' perception towards various investment avenues in Vellore city, Tamil Nadu and India is yet to be explored. This article is therefore timely and fills the gap in investment avenues literature. Furthermore, by pooling small amounts of money into a single investment value, individual investors are able to participate in investment strategies that would have otherwise been financially unfeasible. The Indian investment industry is witnessing a rapid growth as a result of infrastructural development, manufacturing and service sector, in personal financial assets and rise in foreign participation. With the growing risk appetite, rising income, and increasing awareness. Mutual funds and shares are becoming a preferred investment vehicles like bank fixed deposits and post office savings that are considered safe. The present empirical study is an attempt to examine the investors' perception towards various investment avenues in Vellore city, Tamil Nadu, India. Design/Methodology/Approach: Primary data using convenient sampling through questionnaire and interview method as well as secondary data from wide range of literature from various journal publications had been utilized. Frequency distribution, percentage analysis, Mann Whitney and Kruskal-Wallis Test were used to test the objectives of the study. In order to test the reliability of the scale, the researchers applied Cronbach's Alpha (CFA) to measure the internal consistency of the variables. Findings: The findings of the study on investors' perception towards various investment avenues emphasized that the aged and high income investors prefer to invest only in post office and bank deposits for safety investment reason. Originality/Value: An Empirical Analysis on Investors' perception towards various investment avenues in Vellore city, Tamil Nadu and India is the original work of the authors.

Keywords: Investors perception, Investment avenues and pattern, decision making, risk factor.

\section{Introduction}

Financial markets play a vital role in the economic development of a country. They facilitate the allocation of scarce resources by transferring them from savers to borrowers, thereby accelerating investment activities in the country (Deepak Chawla, 2014). Traditional finance theory believes on the principle that investors rational and they process all the available information and take rational decisions. However many researches and studies have proven that investors depict a irrational behaviour by making systematic errors during decision making process. Behavioural finance is a new field emerged in the last 25 years that studies how finance is affected by psychology. It combines behavioural and cognitive psychology theory with conventional economics and finance to provide explanations for people's behaviour in financial settings and their economic decisions (Nisha Shankar, 2014).

Many individuals find investments to be fascinating because they can participate in the decision-making process and see the results of their choices. Not all investments will be profitable, as investor will not always make the correct investment decisions over the period of years. Investment is not a game but a serious subject that can have a major impact on investor's future wellbeing. Virtually everyone makes investments. Even if the individual does not select specific assets such as stock, investments are still made through participation in pension plan, and employee savings programme or through purchase of life insurance, home, gold, silver, bonds, post office savings or real estate. Each of the investment has common characteristics such as potential return and the risk. The future is uncertain, and one must determine how much risk you are willing to bear since higher return is associated with accepting more risk (Pandian, 
2011). Based on the above backdrop, an empirical attempt has been made in this paper to study the investors' perception towards various investment avenues in Vellore city, Tamil Nadu and India.

\section{Investment - Concept}

Investment refers to purchase of financial assets. While investment goods are those goods which are used for further production. Investment is a conscious act of an individual or any entity that involves development of money in securities or properties issued by any financial institutions with the objective of high returns with in a definite period of time (Mahendra Kumar Ikkar, 2014).

\section{Perception of Women Investors towards Investment Avenues in India}

In the words of Pandit Jawaharala Nehru, former Prime Minister of India, "When women move forward, the family moves, the village moves and the nation movies", is the central theme in the socioeconomic paradigm of the nation as it is an accepted fact that only when women are in the mainstream of progress can any economic and social development be meaningful. Traditionally, women have great propensity to save and invest in shares, bonds, jewelry, post office, banks and insurance. The perception and tendency is increasing over the decades on account of women's dynamic role in very economic activity. Today, a great number of women are career oriented, are employed in jobs, and are earning their livelihood. Women's attitude towards investment avenues has also been changing, and they are open to make financial investments that have greater risk (Paramashivaiah, 2014).

\section{Literature Review}

The review of literature made for this study on perception of investor's towards various investment avenues shows that the major impact is based on decision making of all investors. To justify the need of present study, following literature has been reviewed.

Sujit and Amrit (1996), stated that the main factor influenced the salaried and business class group to invest in mutual fund were tax benefit. Agarwal (2001), suggested that the public provident fund is the most beneficial investment for all group of people (salaried class, self-employment and retired persons) as well as for both tax payer and non-tax payer. Tapan and Nalini (2002), expressed that investors are very much concerned about the safety and minimum return for the amount invested in the mutual fund. Factors like tax rebate under section $80 \mathrm{C}$ and past performance of the company will also be taken into consideration by investor before making investment. Chalam (2003), argued that the majority of the investor the first choice of investment is real estate and the second preference to the mutual fund schemes followed by gold and other metals. Singh (2006), analyzed that investment decisions making done by the majority of investor based on the recommendation done by the professionals and financial advisors. Muttapan (2006), concluded that the factors influencing to invest in mutual fund are tax exemption. Ranganathan (2006), studied that the retirement purpose the investors preferred to invest in the pension fund as well as provident fund and they were not preferred to investment in mutual fund for their future need. Mittal et al, (2007) stated that service class, business class, housewives, professionals and students are preferred to invest in equity/mutual fund, debenture/bonds, real estate/ bullions, post office deposits/derivatives and derivatives/equities respectively. IIM Data work (2007) analyzed that there is an association between education level and financial behavior of the investor. Irrespective of the educational deposits in the bank is popular among all the investor. Mitta and Vyas (2008), studied that the demographic information such as age, educational qualification, income and marital status will have significant effect of an investor investment decision. Gupta and Jain (2008), analyzed the main reservations of the investors towards mutual fund are volatility, price manipulation, wrong attitude of brokers, mismanagement of corporate executives.

Parihar et al, (2009), pointed out that return followed by liquidity, flexibility, affordability and transparency are the influential factors to make investment in mutual funds by the investor. Krishnamoorti (2009), pointed out that investor educational backgrounds, job, reading habit of news relating to investment are closely associated with the investment decision of investor. Saravana Kumar (2010), in his study the factors influenced the investors to invest in equity shares are liquidity, low investment and capital appreciation. Lalita Mohan (2010), argued that the various investment channels should be keeping updated to the investor through print and electronic media. The bank employees believed that insurance is an investment avenue rather than risk coverage instrument. Sasi Kumar and Vikkaraman (2010), stated in his article that the investor preferred to invest in gold followed by bank for the safe investment. For the security purpose the investors are preferred to invest in insurance. Joseph et at, (2011), expressed that the knowledge of the investor about the investment avenues are low. Pati and Shome (2011), reviewed that the secured avenue of bank deposit 
schemes are preferred by households rather than unsecured avenues of savings even though it gives high return.Alex Wang (2011), expressed that variables like awareness, income level and skill plays a vital role which influence youngster to invest in mutual funds. Sarita (2011), found that the irrespective of educational qualification, job, age, income level investor would like to protect their future by taking an insurance policy. Yogesh and Charuly (2012), analyzed that due to low returns the conventional investment options like Post Office Saving Schemes, Public Provident Funds are not preferred by the investors. However, investment on gold is preferred by female investors. Kaushal and Kinjal (2012), discussed that due to less risk all income group and category of investor prefer to invest in bank deposits as well as post office deposits. Whereas investment in equity shares, mutual funds, insurance, commodities and real estate are preferred by higher income group with higher education. Palanivel and Chandrakumar (2013), identified the low and middle income group of investor and irrespective of them give preference to invest in insurance and bank deposit. Uma Maheswari and Ashok Kumar (2014), suggested that majority of investors preferred to invest in Fixed deposit with banks followed by gold, units of UTI, fixed deposit of non-government companies, mutual funds, equity shares and debenture for safety and liquidity. The above literature shows the important contribution on investors perception towards' various investment avenues. It is also evident from the above literature that majority of the investors prefer fist safety and security for the investment and secondly they interested to get maximum benefits for their investments. In light of above literature, the present study attempts to identify the problems on the perception of investors towards investment avenues in Vellore city, Tamil Nadu.

\section{Statement of Problem}

The literature cited above does not discuss the investment behaviour/perception of investors in various investment avenues available in India in the sense that no attempt is made to extract the important underlying factors of investment, their relative importance and their relationship with demographic variables. Majority of the studies prove contradictory results of investor' perception towards various investment avenues in India. The present work takes care of these research gap.

\section{Research Question}

In this study the researchers are seeking to answer the following questions.

Are the investment decision taken by the investors across gender is same?

What are the major factors influencing the investor towards selection of various investment avenues in Vellore city.

\section{Objectives of the Study}

The following objectives were framed to know the investors perception towards various investment avenues.

1. To understand the effect of demographic factors affecting the choice of investment.

2. To identify the investment decision towards various investment avenues taken by investors across gender.

3. To ascertain the factors influencing the investor towards selection/order of preference of various investment avenues.

4. To find out the perception of investors relating to safety, liquidity and high returns dimensions.

\section{Hypothesis}

1. Ho1. There is no significant difference in taking investment decisions towards various investment avenues across the gender.

2. Ho2. There is no significant difference in the order of preference of various investment avenues across the age and income level of the respondent.

3. Ho3. There is no significant difference in the perception of investors related to safety, liquidity and high returns.

\section{Research Methodology}

An empirical study was undertaken by reiewing the literature on the subject. A strucutured questionnaire was framed and distributed to the respondents through direct interview method and it contains two parts. First part deals with demographic profile containing open, close ended questions. Second part of the questionnaire contains Likert's scale questions relating to investors' perception towards various investment avenues. Primary data was used to collect the questionnaire from the target respondents and secondary data was used to collect articles, magazine and reports. 
Convenience sampling technique was used to collect the samples from Vellore city only. A sample of 145 issued to the respondents of the total population and collected only 121 and finally only 100 samples are taken in to account for anlaysis and balance 21 was not considered due to incomplete response. IBM SPSS 20 version software was used for analysis and statistical tools like frequency distribution, percentage analysis, Mann Whitney and Kurshall Wallis test was used to interpret the data.

\section{Test of Normality}

The statatistcal tests that can be relied upon for testing the above hypothesis would either be prametric or non-parametric depending upon the normality of data. In general, parametric tests assume the data is normally distributed while nonparametric test do not go with the underlying assumptions of normality. Accordingly, one way analysis of variane is used to under parametric category and Kruskal-Wallis and Mann Whitney test is used under non-parametric category. In this connection, it is necessary to check the data for normality. Null hypothesis assumes that data is normally distributed and finally the results rejects the null hypothesis. It can be conculded that the calculated value of one way annova is 0.000 which is less than the hypothetical value at 0.05 (Deepak Tandon, 20140). Therefore, the study proceeds with the application of Mann Whitney and Kruskal-Wallis test to find out if there is any significant association between income, education with factors influencing investors towards selection of vaious investment avenues.

\section{Realiability Testing}

The reduced set of 9 items was tested for reliability using Cronbach Alpha. The Cronbach Alpha was 0.782 for the 100 sets of responses. This shows a fair degree of internal onsistency amongst the items.

\section{Limitations}

Though the present research paper is aimed to achieve the above-mentioned objective in full earnest and accuracy, there are certain limitations. The time factor was the main limitation for completion of the research, and the study was conducted targeting the investors in Vellore city only. The primary data has been collected through a structured questionnaire from a sample of only 100 investors in Vellore city, which may not reflect the opinion of the entire population. The study period is resticted to six months only i.e., from April 2014 to September 2014.

\section{Analysis and Discussion}

\subsection{Percentage analysis}

The data pertaining to demographic profile of the respondents were given in table 1

Table 3. Demographic profile

\begin{tabular}{|c|c|c|c|}
\hline Vaniables & Category & Frequency & Percentage \\
\hline \multirow[t]{2}{*}{$\begin{array}{l}\text { Gender } \\
\end{array}$} & Male & 55.1 & 55.1 \\
\hline & Female & 44.9 & 44.9 \\
\hline \multirow{6}{*}{ Age } & $\begin{array}{l}\text { Total } \\
21-30\end{array}$ & $\begin{array}{l}100 \\
38.8\end{array}$ & 100 \\
\hline & $31-40$ & 22.4 & 22.4 \\
\hline & & & \\
\hline & $51-60$ & 62 & 62 \\
\hline & Above 60 & & 6.1 \\
\hline & Total & 100 & 100 \\
\hline \multirow[t]{4}{*}{ Education } & Plus 2 & 24.5 & 24.5 \\
\hline & UG & 26.5 & 26.5 \\
\hline & $\begin{array}{l}\text { PG } \\
\text { Professionals }\end{array}$ & & \\
\hline & Professionals & 12.3 & ${ }_{100}^{12.3}$ \\
\hline \multirow{5}{*}{ Sector employment } & Govemment & & \\
\hline & Pivate & 367 & 36.7 \\
\hline & Self-employment & 205 & 205 \\
\hline & Retired & & 6.1 \\
\hline & Total & 100 & 100 \\
\hline \multirow[t]{4}{*}{ Annual income } & Up to 2 lacks & 36.7 & 36.7 \\
\hline & & & \\
\hline & 4-6 a acks & 晹. & 26.3 20. \\
\hline & $\begin{array}{l}\text { Above } 6 \text { lacks } \\
\text { Total }\end{array}$ & 100 & 10.3 \\
\hline \multirow{3}{*}{ Investment decision } & $\begin{array}{l}\text { Total } \\
\text { Yes }\end{array}$ & 653 & 653 \\
\hline & No & 347 & 347 \\
\hline & Total & 100 & 100 \\
\hline \multirow{5}{*}{ Source of information } & Print/electronic media & & 6.1 \\
\hline & Friends/relatives advice & 44.9 & 44.9 \\
\hline & Experts opinion & 42.9 & 42.9 \\
\hline & Canvas agent & 4.1 & 4.1 \\
\hline & $\begin{array}{l}\text { Others } \\
\text { Total }\end{array}$ & $\begin{array}{l}2.0 \\
100\end{array}$ & $\begin{array}{l}2.0 \\
100\end{array}$ \\
\hline
\end{tabular}




\subsection{Inference}

It is inferred from the above table indicates that $55.1 \%$ of the respondents are male and $44.9 \%$ of the respondents are female respectively. The largest group of the respondents (38.8\%) are in the age group of 21-30 years whereas $22.4 \%$ of the respondents are in the age group of $31-40$ and $26.5 \%$ of the respondents are in the age group of $41-50$ years. $6.1 \%$ of the respondents are above 60 years. Analysis further shows that $24.5 \%$ of the respondents are plus $2,26.5 \%$ of the respondents are under graduates, $36.7 \%$ of the respondents are post graduate and $12.3 \%$ of the respondents are professional. $36.7 \%$ of the respondents are working in government sectors and $36.7 \%$ of the respondents are working in private sectors. With regard to annual income $36.7 \%$ of the respondents are in the annual income up to 2 lakhs. Majority $(65.3 \%)$ of the respondents will take investment decision on their own whereas $34.7 \%$ of the respondents will be depend upon others to take investment decision. The major source (44.9\%) of income for investment in various investment avenues by the investors are from friends and relatives.

\subsection{Mann Whitney Test}

The data pertaining to investment decision taken by investors across gender.

Table 2. Mann Whitney test

\begin{tabular}{|c|c|c|c|c|c|c|c|c|}
\hline \multirow{3}{*}{$\begin{array}{l}\text { Investment } \\
\text { Avenue } \\
\text { Stock market }\end{array}$} & \multirow{3}{*}{$\begin{array}{c}\text { Gender } \\
\text { Male }\end{array}$} & \multirow{3}{*}{$\begin{array}{l}\text { Mann } \\
\text { Whitney U } \\
1006.000\end{array}$} & \multirow{3}{*}{$\begin{array}{l}\mathbf{z} \\
\\
-1.327\end{array}$} & \multirow{3}{*}{$\begin{array}{r}\text { Sig, (2 } \\
\text { tailed) } \\
.185\end{array}$} & \multirow{3}{*}{$\begin{array}{l}\text { Invetsmtn } \\
\text { Decision } \\
\text { Yes }\end{array}$} & \multirow{3}{*}{$\begin{array}{l}\text { Mann } \\
\text { Whitney U } \\
698.000\end{array}$} & \multirow{2}{*}{\multicolumn{2}{|c|}{$\begin{array}{ll}\text { Z } & \text { Asymp } \\
& \text { Sig (2-tailed) }\end{array}$}} \\
\hline & & & & & & & & \\
\hline & & & & & & & \multirow[t]{3}{*}{-2.970} & \multirow[t]{3}{*}{$.003^{*}$} \\
\hline & Female & & & & No & & & \\
\hline & Total & 100 & & & Total & 100 & & \\
\hline \multirow[t]{3}{*}{ Gold } & Male & 756.00 & -3.194 & $.001^{*}$ & Yes & 874.000 & \multirow[t]{3}{*}{-1.653} & \multirow[t]{3}{*}{.098} \\
\hline & Female & & & & No & & & \\
\hline & Total & 100 & & & Total & 100 & & \\
\hline \multirow[t]{3}{*}{ Real estate } & Male & 1112.000 & -.552 & .581 & Yes & 730.000 & \multirow[t]{3}{*}{-2.716} & \multirow[t]{3}{*}{$.007 *$} \\
\hline & Female & & & & No & & & \\
\hline & Total & 100 & & & Total & 100 & & \\
\hline \multirow[t]{3}{*}{ Insurance } & Male & 1096.000 & -.672 & .502 & Yes & 826.000 & \multirow[t]{3}{*}{-1.998} & \multirow[t]{3}{*}{$.046^{*}$} \\
\hline & Female & & & & No & & & \\
\hline & Total & 100 & & & Total & 100 & & \\
\hline \multirow[t]{3}{*}{ Bank savings } & Male & 1070.000 & -.874 & .382 & Yes & 778.000 & \multirow[t]{3}{*}{-2.400} & \multirow[t]{3}{*}{$.016^{*}$} \\
\hline & Female & & & & No & & & \\
\hline & Total & 100 & & & Total & 100 & & \\
\hline \multirow[t]{3}{*}{ Post office } & Male & 836.000 & -2.639 & .008 & Yes & 814.000 & \multirow[t]{3}{*}{-2.146} & \multirow[t]{3}{*}{$.032^{*}$} \\
\hline & Female & & & & No & & & \\
\hline & Total & 100 & & & Total & 100 & & \\
\hline
\end{tabular}

Source: Authors' findings. ${ }^{*}$ Significance at $5 \%$ level.

\subsection{Inference}

It is inferred from the above table that except investment on gold, the calculated value of Mann Whitney test at $5 \%$ level of singnificance on stock market is 0.003 , real estate is 0.007 , insurance is 0.46 , bank savings is 0.016 and post office is 0.032 is less than the hypothetical value at 0.05 .

Hence, (Ho1) null hypothesis is not accpted and there is statistical significant association between gender amd invetors' perception towards various investment avenees. It is also very intersting to observe that male perception towards various investment avenues are more or less equal with female investors'. 


\subsection{Kruskal-Wallis Test}

The data pertaining to age, annual income and investment avenue were given in table 3.

Table 3. Age, annual income and investors' perception towards various investment avenues.

\begin{tabular}{|c|c|c|c|c|c|c|}
\hline Investment Avenue & Age & Chi-Square & Asymp. Sig. & Annual Income & Chi-Square & Asymp. Sig. \\
\hline Stock Market & $\begin{array}{c}21-30 \mathrm{yrs} \\
31 \text { - } 40 \mathrm{yrs} \\
41-50 \mathrm{yrs} \\
\text { Total }\end{array}$ & 22.987 & $.000 *$ & $\begin{array}{c}\text { Upto } 2 \text { lacs } \\
2 \text { - } 4 \text { lacs } \\
4 \text { to } 6 \text { lacs } \\
\text { Total }\end{array}$ & 1.548 & .461 \\
\hline Gold & $\begin{array}{c}21-30 \text { yrs } \\
31 \text { - } 40 \text { yrs } \\
41 \text { - } 50 \text { yrs } \\
\text { Total }\end{array}$ & 15.213 & $.000^{*}$ & $\begin{array}{c}\text { Upto } 2 \text { lacs } \\
2 \text { - } 4 \text { lacs } \\
4 \text { to } 6 \text { lacs } \\
\text { Total }\end{array}$ & 3.593 & .166 \\
\hline Real estate & $\begin{array}{c}21-30 \text { yrs } \\
31 \text { - } 40 \text { yrs } \\
41 \text { - } 50 \text { yrs } \\
\text { Total }\end{array}$ & 4.090 & .129 & $\begin{array}{c}\text { Upto } 2 \text { lacs } \\
2 \text { - } 4 \text { lacs } \\
4 \text { to } 6 \text { lacs } \\
\text { Total }\end{array}$ & 1.949 & .377 \\
\hline Insurance & $\begin{array}{c}21-30 \text { yrs } \\
31 \text { - } 40 \text { yrs } \\
41 \text { - } 50 \text { yrs } \\
\text { Total }\end{array}$ & 5.268 & .072 & $\begin{array}{c}\text { Upto } 2 \text { lacs } \\
2 \text { - } 4 \text { lacs } \\
4 \text { to } 6 \text { lacs } \\
\text { Total }\end{array}$ & 5.757 & .056 \\
\hline Bank savings & $\begin{array}{c}21-30 \text { yrs } \\
31 \text { - } 40 \text { yrs } \\
41 \text { - } 50 \text { yrs } \\
\text { Total }\end{array}$ & 13.675 & $.001^{*}$ & $\begin{array}{c}\text { Upto } 2 \text { lacs } \\
2 \text { - } 4 \text { lacs } \\
4 \text { to } 6 \text { lacs } \\
\text { Total }\end{array}$ & .729 & .695 \\
\hline Post office & $\begin{array}{c}21-30 \text { yrs } \\
31 \text { - } 40 \text { yrs } \\
41 \text { - } 50 \text { yrs } \\
\text { Total }\end{array}$ & 13.702 & $.001^{*}$ & $\begin{array}{l}\text { Upto } 2 \text { lacs } \\
2 \text { - } 4 \text { lacs } \\
4 \text { to } 6 \text { lacs }\end{array}$ & 8.772 & $.012^{*}$ \\
\hline
\end{tabular}

Source: Authors' findings. *significan at $5 \%$ level.

\subsection{Inference}

Table 4 reveals that there is a statistical significant relationship between age and investment avenues of the respondents. The calculated values of Kruskal-Wallis Test except insurance and real estate, all the other variables like share market $(0.000)$, gold $(0.000)$, bank savings $(0.001)$ and post office $(0.001)$ which is less than the hypothetical value $(\alpha=0.05)$ at $5 \%$ level of significance. Hence, null hypothesis ( $\left.\mathrm{H}_{2}\right)$ is not accepted. Therefore, there is statistical significant association between age and perception of investors on various investment avenues. So, the order of preference on investment towards real estate and insurance are same across the age group though it varies with regard to stock market, gold, bank savings and post office.

In addition to above analysis on age and investment avenues of the respondents, the researchers also applied Kruskal-Wallis Test for income and perception of investors towards investment aveues. The calucualed value for post office $(0.012)$ is less than the hypothetical value $(\alpha=0.05)$ at $5 \%$ level of significance. Hence, null hypothesis (Ho2) is not accepted. Therefore, there is statistical significant association between income and perception of investors on various investment avenues and remaining avenues have no significant relationships. So, the order perception on investment towards post office are same across the income level however it is diferent in stock market, gold bank savings and gold.

\subsection{One Way ANOVA}

The data perctaining to perception of investors related to safety, liquidity and high returns relating to investments were presented in table 4. 
Table 4. One way Anova

\begin{tabular}{|c|c|c|c|c|}
\hline \multicolumn{2}{|c|}{ Variable } & \multirow{2}{*}{$\begin{array}{c}\text { Safety } \\
3.35\end{array}$} & \multirow{2}{*}{$\begin{array}{c}\text { Liquidity } \\
3.04\end{array}$} & \multirow{2}{*}{$\begin{array}{c}\text { High return } \\
3.37\end{array}$} \\
\hline Stock market & Mean & & & \\
\hline & $\mathrm{N}$ & 108 & 108 & 108 \\
\hline & Std. Deviation & 1.103 & 1.251 & 1.357 \\
\hline \multirow{3}{*}{ Gold } & Mean & 3.47 & 3.29 & 3.49 \\
\hline & $\mathrm{N}$ & 108 & 108 & 108 \\
\hline & Std. Deviation & 1.236 & 1.184 & 1.220 \\
\hline \multirow{3}{*}{ Real estate } & Mean & 3.35 & 3.22 & 3.51 \\
\hline & $\mathrm{N}$ & 108 & 108 & 108 \\
\hline & Std. Deviation & 1.260 & 1.304 & 1.437 \\
\hline \multirow{3}{*}{ Insurance } & Mean & 3.24 & 3.08 & 3.31 \\
\hline & $\mathrm{N}$ & 108 & 108 & 108 \\
\hline & Std. Deviation & 1.471 & 1.071 & 1.134 \\
\hline \multirow[t]{3}{*}{ Bank savings } & Mean & 3.80 & 3.37 & 3.51 \\
\hline & $\mathrm{N}$ & 108 & 108 & 108 \\
\hline & Std. Deviation & 1.421 & 1.487 & 1.220 \\
\hline \multirow[t]{3}{*}{ Post Office } & Mean & 3.78 & 3.51 & 3.57 \\
\hline & $\mathrm{N}$ & 108 & 108 & 108 \\
\hline & Std. Deviation & 1.320 & 1.150 & 1.284 \\
\hline \multirow[t]{5}{*}{ Total } & Mean & 3.50 & 3.25 & 3.46 \\
\hline & $\mathrm{N}$ & 647 & 647 & 647 \\
\hline & Std. Deviation & 1.320 & 1.254 & 1.277 \\
\hline & F value & 3.491 & 2.156 & .668 \\
\hline & Sig value & .004 & .057 & .648 \\
\hline
\end{tabular}

Source: Authors' findings.

\subsection{Inference}

For stock markets, safety achieved a mean score of 3.35 while for gold it was 3.47 . For real estate safety achieved a mean score of 3.35. For insurance with a mean score of 3.24 and for bank savings with a mean scores of 3.80 . The mean score achieved by safety for post office was 3.78. An analysis of the above table brings out that the F-value is 3.491 and significance is 0.004 . Since the significance value is less than 0.05 , the mean differences existing only for safety as an investment reason across various investment avenues are significant at $5 \%$ level.

\section{Findings}

The present study has revealed that the order of preferencce towards various investment aveunes are same across the gender except gold and post office. The decision making on investment avenues are same among the genders on gold. The order of preferencce towards real estate and insurance are same across the age group though it varies with regard to stock market, gold, bank savings and post office. In the present study the perception of order of investment towards post officce are different among the various income level of the respondent.

\section{Conclusion}

The study concludes that investment done in various investment avenues with the expectation of capital appreciation and short and long term earnings. The basic idea behind investment of all government, private, self-employed and retired person in this study is to utilize the surplus money in favourable plans so that the money will be rolled back as well as it will give high returns also. When a common men thinks about investment he will never go for any risky plan. In the present scenario the share and gold market is highly uncertain and unpredictable, so the investor should analyse the market cautiously and then make investment decision. 


\section{Suggestions for Future Research}

It is suggested that the study may be replicated with investors' perception towards various investment avenues like stock market, gold, bank deposits, insurance and post office to other Metro cities in Tamil Nadu or other major cities in North state of India. Further an attempt can also be made to study the risk factors involved in investment decision on shares and gold.

\section{References}

Alex Wang, (2011), 'Younger Generations' Investing Behaviors in Mutual Funds: Does Gender Matter? The Journal of Wealth Management, spring', Vol. 13, No.4, pp.13-23. http://dx.doi.org/10603/9430/15/15.

Alexander, G., Jones, J., Nigro, P, (1998), Mutual Fund Shareholders: Characteristics, Investor Knowledge, and Sources of Information', Financial Services Review, Vol.7, pp.301-316. www.mits/oan.mit.edu/faculty/pdf/cv/alexander.

Allan, Lee, Yingzi Xu, Kenneth Hyde. F, (2013), Factors Influencing Strive Choice of Retirement Funds', Journals of Financial Services Marketing', Vol.18, No.2, pp.137-151. www.emeraldinsight.com/http://dx.doi.org /10.1108.

Agarwal, S. P, (2001), Public Provident Fund Account - A Matchless Investment Scheme, Southern Economist, Vol.39, No.20, pp.15. http://dx.doi.org/10603/9430/15/15

An IIMS Data works Research Report (2007), Invest India Income and Savings Survey among 321 Million Paid up Workers between the Ages of 18 and 59. www.tribuneindia.comdx.doi.org/20071010

Bhatt, Kaushal, A. and Bhatt, Kinjal, (2012), Effects of Investor Occupation and Education on Choice of Investment: An Empirical Study in India', International Journal of Management, Vol. 29, No. 4.

Chalam, G. V, (2003), Investors Behavioural Pattern of Investment and Their Preferences of Mutual Funds, Southern Economist, Vol.41, No.19, pp.13. http://dx.doi.org/10603/9430/15/15

Deepak Tandon, Kamini Tandon and Niddhi Malhotra, (2014), An Evaluation of the Technical, Pure Technical and

Scale Efficiency in the Indian Banking Industry Using Data Envelop Analysis, Vol.15, No.3, pp.545-563.

Deepak Chawla, (2014), An Empirical Analysis of Factors Influencing Investment in Mutual Funds in India, Global Business Review, Vol.15, Issue 3, pp.493-503.

Gupta L. C and Jain, (2008), The Changing Investment Preferences of Indian Households, www.scmrd.org.

Grable, J. E and Joo, S, (2000), A Cross-disciplinary Examination of Financial Risk Tolerance, Consumer Interests Annual, Vol.46, pp.151-157. www.springer.com/http://dx.doi.org/10.1023/3A1025443204681

Jacobs-Lawson, J. M and Hershey, D. A, (2005), Influence of Future Time Perspective, Financial Knowledge and Financial Risk Tolerance on Retirement Savings Behaviours, Financial Services Review, Vol.14, pp.331- 344. http://psychology.okstate.edu.

Jones, G, J, Nigro, P, (1998), Mutual Fund Shareholders: Characteristics, Investor Knowledge, and Sources of Information', Financial Services Review, Vol.7, pp.301-316. www.mitsloan.mit.edu/faculty/pdf/cv/alexander.

Joo. S, (2000), A Cross-disciplinary Examination of Financial Risk Tolerance',' Consumer Interests Annual, Vol.46, pp.151-157. www.springer.com/http://dx.doi.org/10.1023/3A1025443204681

Joseph Anbarasu, D, Clifford Paul, S and Annette, B, (2011), An Empirical Study on Some Demographic Characteristics of Investors and its Impact on Pattern of their Savings and Risk Coverage Through Insurance Schemes, The IUP Journal of Risk \& Insurance', Vol.8, No.1, pp.7. www.ssrn.com/http://dx.doi.org/l3.1783523

Kasirajan, (2004), A Study on the Attitude of Investors Towards Various Forms if Investment in Tuticorin, M.phil, Dissertation, M.S.University, August.

Krishnamoorthi, C, (2009), Changing Pattern of Indian Households: Savings in Financial Assets, RVS Journal of management, Vol.2, No.1, pp.79-90. http://dx.doi.org/10603.9430.15.15.

Kaushal, A and Bhatt, Kinjal, (2012), Effects of Investor Occupation and Education on Choice of Investment: An Empirical Study in India, International Journal of Management, Vol.29, No.4.

Lee, Yingzi,Xu, Kenneth Hyde. F, (2013), Factors Influencing Strive Choice of Retirement Funds', Journals of Financial Services

Marketing, Vol.18, No.2, pp.137-151. www.emeraldinsight.com/http://dx.doi.org/10.1108.

Lu Zheng, (1999), Is Money Smart? A Study of Mutual Fund Investors' Fund Selection Ability, The Journal of Finance,Vol.54,No.3, pp.901-933. ww.etf.com/dx.doi.org/9429.

Lawson, J. M and Hershey, D. A, (2005), Influence of Future Time Perspective, Financial Knowledge, and Financial Risk Tolerance on Retirement Savings Behaviours, Financial Services Review, Vol.14, pp.331-344. http://psychology. okstate.edu.

Lalit Mohan Kathuria and Kanika Singhania, (2010), Investor Knowledge and Investment Practices of Private Sector Bank Employees, The Indian Journal of Commerce, Vol. 63, No.3, pp.79. http://dx.doi.org/10603/9430/15/15

Mahendra Kumar Ikhar, (2014), Investor's Attitude Towards the Selection of Investment Option With Special Reference to Derivative Investments, Asian Journal of Management, Vol.5, No.2, pp.145-149.

Mittal M and A. Dhade, (2007), Gender Difference An Investment Risk-Taking: An Empirical Study, The ICFAI Journal of Behavioural Finance, Vol.4, No.2, pp.32-42. www.shodhganga.inflibnet.ac.in/http://dx.doi.org/10603/9430/15/15.

Muttapan, P. K, (2006), Factors influencing Mutual Fund Investment Decision Making, Southern Economist, pp.7-10. www.ischolar.in/http://dx.doi.org/37826 
Mittal, M and Vyas R. K, (2008), Personality Type and Investment Choice: An Empirical Study, ICFAI Journal of Journal of Behavioral Finance, Vol.5, No.3, pp.6-22. www.shodhganga.inflibnet.ac.in/dx.doi.org/10603.9430.15.15.

Nisha Shanker and Sakthi Srinivasan, K, (2014), Investors Behaviour and Decision Making Model in Stock Market: A Literature Survey, International Journal of Applied Business and Economic Research, Vol.12, No.1, pp.99-118. www.bschool.vit.ac.in/faculty/ 68082094

Nigro, P, (1998), Mutual Fund Shareholders: Characteristics, Investor Knowledge, and Sources of Information, Financial Services Review, Vol.7, pp.301-316. www.mitsloan.mit.edu/faculty/pdf/cv/alexander.

Pandian. P, (2011), Investment Pattern on Employees, HRM Times, The Professional Journal, Vol.13, No.2, pp.35-36.

Paramashiviah, P, Puttaswamy and Ramya, S. K, (2014), Changing Risk Perception of Women Investors: An Empirical Study, Indian Journal of Finance, Vol.8, No.6, pp.22-32. www.indianjournaloffinance.co.in/archives/june2014.html

Praba, and Suyam, R, (2011), Investors' Decision Making Process and Pattern of Investments: A Study of Individual Investors in Coimbatore, Vol.7, No.2, pp.1-12.

Prabakaran, G and Jayabal, G, (2009), Investors Risk Tolerance Towards Mutual Fund Investments, Sothern Economist, Vol.48, No.4, pp.27. www.shodhganga.inflibnet.ac.in/dx.doi.org/10603/9430.15.15

Parihar, Rajeev Sharma and Deepika Singh parihar, (2009), Analysing Investors Attitude Towards Mutual Funds as a Investment Option, The ICFAI an Journal of Management Research, Vol.8, No.7, pp.56. http://dx.doi.org/10603/9430/15/15

Palanivelu, V.R. \& Chandrakumar, K. (2013).'A Study on Preferred Investment Avenues among Salaried Peoples with Reference to Namakkal Taluk, Tamil Nadu, India, IBEA International Conference on Business, Economics and Accounting, Vol.3, No.11, pp.203-212. http://www.caal-inteduorg.com/ibea2013/ejournal/089.

Pati, A. P and Shome, D, (2011), Do Households Still Prefer Bank Deposits? An Analysis of Shift in Savings and Savings Determinants, The IUP Journal of Bank Management, Vol.10, No.1, pp.46. http://ssrn.com/abstract=1793004.

Ranganathan, K, (2006), A Study of Fund Selection Behaviour of Individual Investors Towards Mutual Funds: With Reference To Mumbai City, ICFAI Journal of Behavioural Finance, Vol.3, No.2, pp.63-88. www.i-scholar.in/http://dx.doi.org/37826.

Ranjith, V. K, (2002), Risk Preference of Investors in the City of Ahmedabad, Finance India, Vol.XVI, No.2, www.financeindia.org.

Saravana Kumar,S, (2010), An Analysis of Investor Preference Towards Equity and Derivatives, The Indian Journal of Commerce, Vol. 63, No.3, pp-71. www.ijcaonline.org/dx.doi.org/20.16914-7014.

Sarita aggrawal and Monika Rani, (2011), Attitude towards Insurance Cover, The IUP Journal of Risk and Insurance, Vol.8, No.1, pp.62. www.pezzottaitejournals.net/dx.doi.org/1365

Sasi Kumar, K.C and Vikkraman, P, (2010), Investors Preference on Financial Service, An International Journal Global Business and Management Research, Vol.2, No.2, pp.253-274. http://dx.doi.org/9425815b.

Saptarshi purkayastha, (2008), Investor Profiling and Investment Planning: An Empirical Study, The Icfaian Journal of Management Research, Vol.7, No.12, pp.17-40. http://dx.doi.org/18655853.

Singh, J and Chander, S, (2006), Investors' Preference for Investment in Mutual Funds: An Empirical Evidence, The ICFAI Journal of Behavioral Finance, Vol.3, No.1, pp.7-17.

Sornaganesh, V. Karthikeyan, (2014), Investors Perception towards Investment, International Journal of Informative and Futuristic Research, An Enlightening Online Open Access, Refereed and Indexed Journal of Multidisciplinary Research ',Vol.1, no.9,pp.5567.

Soumya Saha and Munmun Dey, (2011), Analysis of Factors Affecting Investors' Perception of Mutual Fund Investment, The IUP Journal of Management Research, Vol. 10, No.2, pp.23-44. http://dx.doi.org/1983722

Stinerock, Rober, N, Barbara B. Stern and Michael R. Solomon, (1991), Gender Differences in the Use of Surrogate Consumer for Financial Decision-Making, Journal of Professional Services Marketing, Vol.7, No.2, pp.167-182.

Sujit, S and Amrit, P, (1996), Financial Services: Investment in Equity and Mutual Funds - A Behavioural Study, Deep and Deep Publication, Vol.10, pp.136-145. https://dx.doi.org/22716159.

S. P, (2001), Public Provident Fund Account - A Matchless Investment Scheme, Southern Economist, Vol.39, No.20, pp.15. http://dx.doi.org/10603/9430/15/15

Survey, (2008), conducted by Society for Capital Market Research and Development, New Delhi. www.scmrd.org.

Tapan, K and Nalini Prava Tripathy, (2002), Customer Orientation in Designing Mutual Fund Products: An Analytical Approach to Indian Market Preferences, Finance India, Vol.16, No.3, pp.991-1003.

Umamaheshwar, S and Ashok Kumar, M, (2014), A Study on the Investment Prospective of the Salaried Strata at Coimbatore District, International Journal of Research in Business Management, Vol.2, No.2, pp.99-108.

Wang, (2011), Younger Generations' Investing Behaviors in Mutual Funds: Does Gender Matter? The Journal of Wealth Management, spring', Vol.13, No.4, pp.13-23. http://dx.doi.org/10603/9430/15/15.

Yogesh P and Charul, Y, (2012), A Study of Investment Perspective of Salaried People in Private Sector, Asia Pacific Journal of Marketing and Management Review, Vol.1, No.2, pp.127-146. 